\title{
Synthesis and Biological Activity of a New Type of PM-Toxin Analogue Containing Oxygen Atoms in the Carbon-Chain Skeleton
}

\author{
Yoshikatsu Suzuki, S. J. Danko, ${ }^{*}$ Yoshiki Kono, \\ J. M. DALY,* H. W. KNOChE* \\ and Setsuo TAKEUCHI \\ The Institute of Physical and Chemical Research, \\ Wako-shi, Saitama 351, Japan \\ * Department of Agricultural Biochemistry, University of Nebraska, \\ Lincoln, Nebraska 68583-0718, U.S.A.
}

Received September 5, 1988

\begin{abstract}
PM-toxins are host-specific pathotoxins produced by the corn fungal pathogen Phyllosticta maydis. Three PM-toxin analogues of a new type which have oxygen atoms in the skeletal carbon chain were synthesized as stereoisomeric mixtures. The linear ester PML-777 was about 100-times less active than the potent synthetic analogue PM-777 in an NADH oxidation assay using corn mitochondria. A large cyclic analogue, $\mathrm{PMC}_{32}-7777$, was only about 4- to 10-times less active than the parent linear ester PML-777, but over 500-times more active than a smaller sized analogue, $\mathrm{PMC}_{20^{-}}$ 711. The striking loss of biological activity in PML-777 clearly shows the significance of a carbonchain skeleton like PM-777 for higher biological activity. The unexpectedly slight decrease of activity from PML-777 to $\mathrm{PMC}_{32}-7777$ may suggest that the active conformation of the linear analogue (PML-777) was similar to that of the cyclic analogue (PMC $\left.{ }_{32}-7777\right)$.
\end{abstract}

PM-toxins (A to D), ${ }^{1}{ }^{3)}$ the host-specific pathotoxins which selectively damage only corn with Texas male-sterile cytoplasm (Tmscorn), were previously isolated from the fungal corn pathogen Phyllosticta maydis. Interestingly, each related component showed biological activity almost identical to that observed for HMT-toxins ${ }^{4} \sim 6$ ) isolated from the taxonomically distinguished corn fungal pathogen Helminthosporium maydis (race T), which also damages only Tms-corn. We are interested in understanding the structureactivity relationships and the modes of action of these toxins. Various analogues of HMTtoxin and PM-toxin, including a stereoisomeric mixture of PM-toxin B, were previously synthesized, ${ }^{7 \sim 9)}$ and the results clarified some structural requirements for the higher hostspecific toxicity. One of the prominent factors required for potent activity was molecular flexibility of the skeletal carbon chain to make involved conformations. Namely, an increase of the rigidity by introducing either a shorter or conjugated diene spacer like PM-373, -575, -595 , PM-777t or PM-B' caused a marked decrease of activity (Fig. 1), while the carbon asymmetry and the orientation and spacing of oxygenic groups in the carbon straight-chain had little or no significant influence on the activity.

Based on these results, we attempted to synthesize a new type of PM-toxin analogue, PML-777, $\mathrm{PMC}_{32}-7777$ and $\mathrm{PMC}_{20}-711$, all of which contained ester linkages in the long straight carbon-chain skeleton (Fig. 2), in order to clarify the active conformation of PMtoxins. PML-777 is a linear bisester analogue; the other two are cyclic analogues related to PML-777, PMC $_{32}-7777$ being a large-sized cyclic analogue corresponding to a ring form of PML-777, and $\mathrm{PMC}_{20}-711$ being a mediumsized analogue. The linear type of analogue 


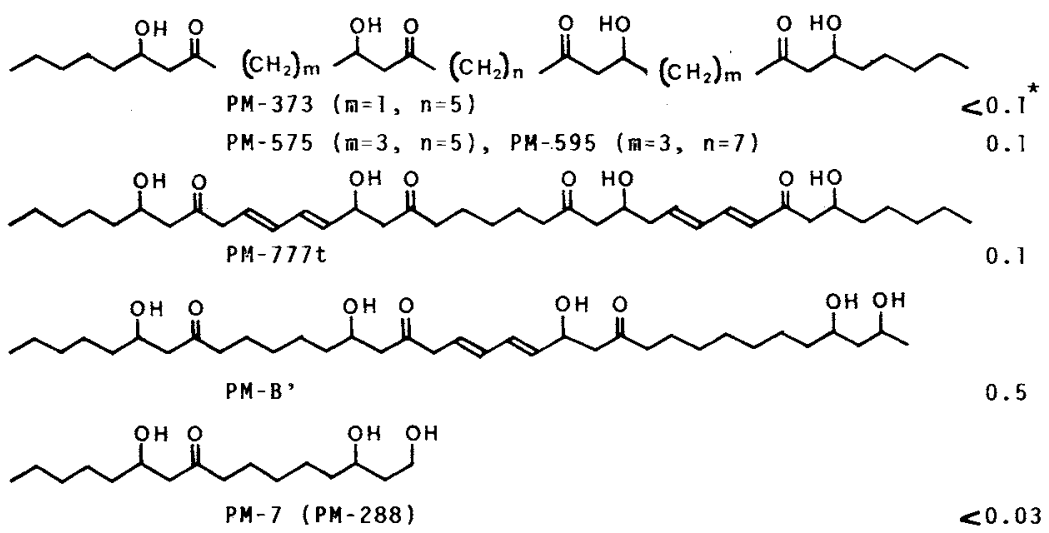

Fig. 1. Structure of Some Potent Synthetic Analogues and Their Relative Activity on NADH Oxidation in Mitochondria.

*Relative activity $(\%)$ when the activity of native PM-toxins was set at $100 \%$.
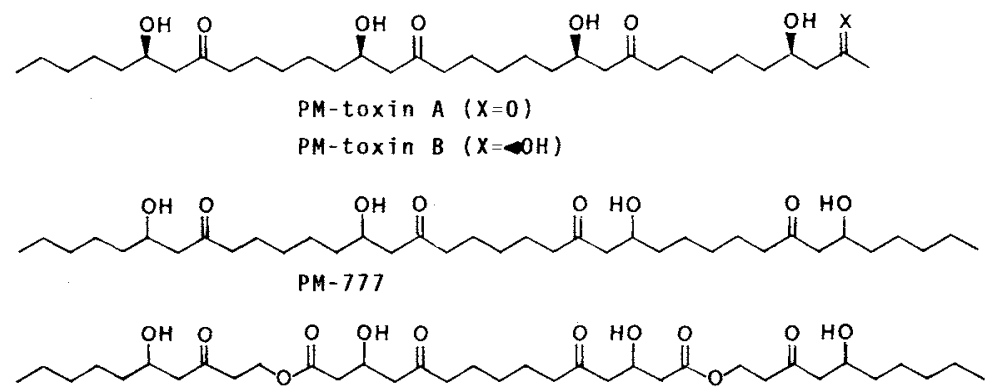

PML -777

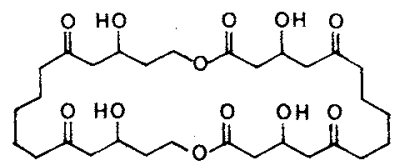

$\mathrm{PMC}_{32}-7777$

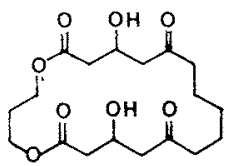

$\mathrm{PMC}_{20}-711$

Fig. 2. Structure of Native PM-Toxins A and B and New Synthetic Analogues.

PML-777 was especially expected to retain higher toxic activity because the orientation, spacing of oxygenic groups and the chain length are the same as those of PM-777, which possesses potent biological activity.

This paper describes the syntheses and biological activity of PML-777 and two of its cyclic analogues, $\mathrm{PMC}_{32}-7777$ and $\mathrm{PMC}_{20^{-}}$ 711 (Fig. 2).

\section{Results and Discussion}

The synthetic outlines of PML-777, $\mathrm{PMC}_{32}$ -
7777 and $\mathrm{PMC}_{20}-711$ are shown in Figs. 3 and 4. Intermolecular condensation between fragments $\mathrm{A}$ and $\mathrm{C}$ led to the corresponding linear analogue, PML-777, while intramolecular condensation between fragments $\mathrm{A}$ and $\mathrm{B}$ (or 1,3propanediol) led to the corresponding cyclic analogues, $\mathrm{PMC}_{32}-7777$ and $\mathrm{PMC}_{20^{-711}}$, respectively. All the analogues were stereoisomeric mixtures.

The preparation of fragments $\mathrm{A}$ and $\mathrm{B}$ starting from bis- $\beta$-oxoester $\mathbf{1}^{10)}$ is shown in Fig. 3. Treatment of 1 with 1,2-ethanedithiol (3 equiv.) and boron trifluoride etherate in di- 


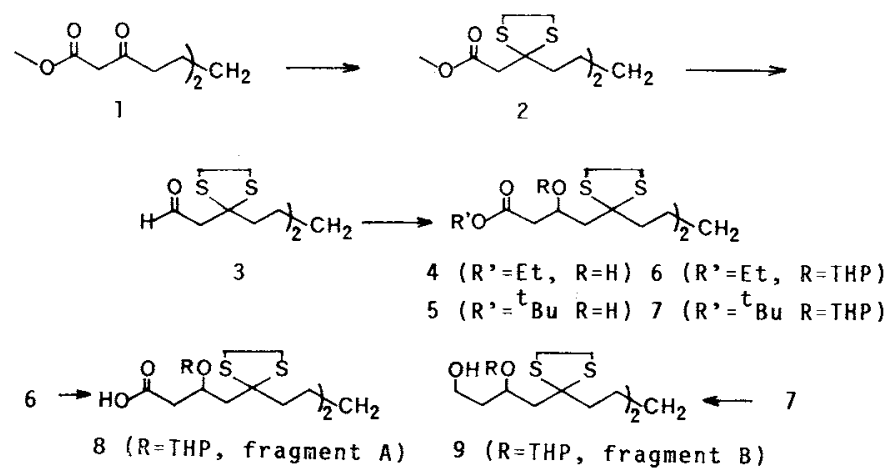

Fig. 3. Synthetic Scheme for Fragments A and B (8 and 9) Leading to PML-777, $\mathrm{PMC}_{32^{-}} 7777$ and $\mathrm{PMC}_{20^{-}}$ 711.

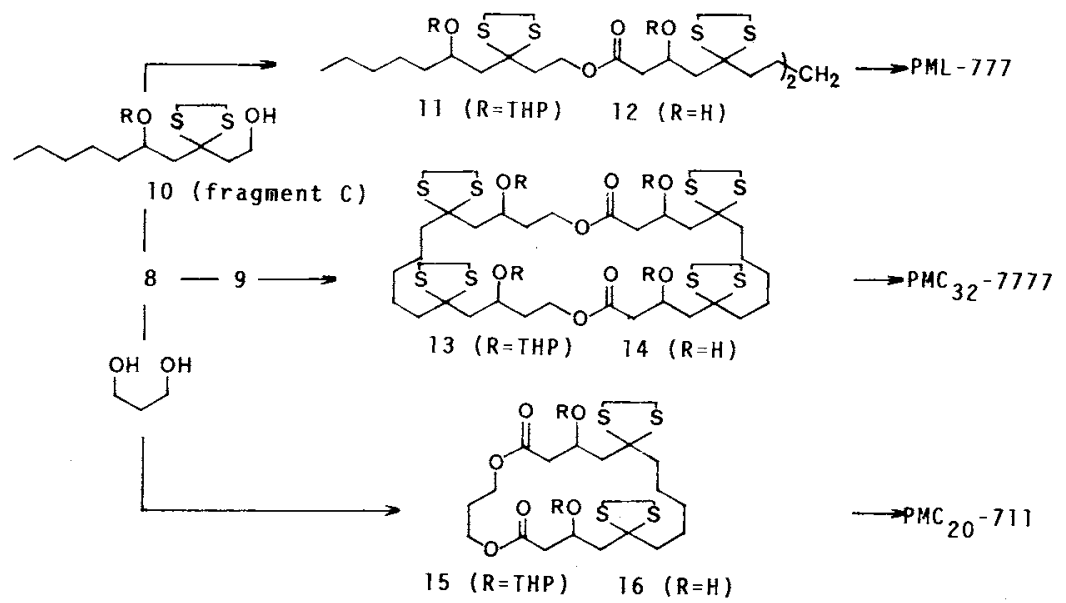

Fig. 4. Synthetic Scheme for PML-777, $\mathrm{PMC}_{32}-7777$ and $\mathrm{PMC}_{20}-711$. :

chloromethane at room temperature afforded bisthioketal 2 in a $76 \%$ yield. Reduction of 2 with an excess of lithium aluminum hydride and subsequent Swern's oxidation ${ }^{11)}$ of the resulting diol gave the corresponding dialdehyde 3 in an $89 \%$ yield. Condensation of the enolate anion of tert-butyl acetate ( 2 equiv.) with 3 gave the bisaldol adduct 5 (c. 100\%). After protecting the hydroxyl functions of 5 as its THP ether by treating with an excess of dihydropyran and $p$-toluenesulfonic acid in dioxane, reduction of the tert-butyl ester 7 with lithium aluminum hydride gave the desired fragment B (9) in an almost quantitative yield. Fragment $\mathbf{A}(\mathbf{8})$ was obtained from the corresponding isopropyl acetate adduct 4 in a $77 \%$ yield, via saponification of the ethyl ester of the THP derivative 6 with sodium hydroxide in aqueous methanol because conversion of the tert-butyl adduct 7 to fragment $\mathrm{A}$ by saponification failed.

The preparation of PML-777 and the two cyclic analogues is shown in Fig. 4. Esterification or lactonization between fragment $\mathrm{A}(\mathbf{8})$ and each alcohol fragment $\left(9,10^{8)}\right.$ and 1,3-propanediol) was accomplished by treating with equimolar amounts of dicyclohexylcarbodiimide (DCC) in the presence of dimethylaminopyridine ${ }^{12)}(0.1$ equiv. $)$ as a catalyst ar room temperature. Lactones $\mathbf{1 3}$ and 15 could not be obtained in analytically pure forms and, therefore, each conjugate was treat ed with warm aqueous acetic acid containing tetrahydrofuran or refluxed with dilute hy- 
Table I. ${ }^{13}$ C-NMR Data of SynthetiC Analogues

$\left(22.5 \mathrm{MHz}, \mathrm{CDCl}_{3}, \mathrm{ppm}\right)$

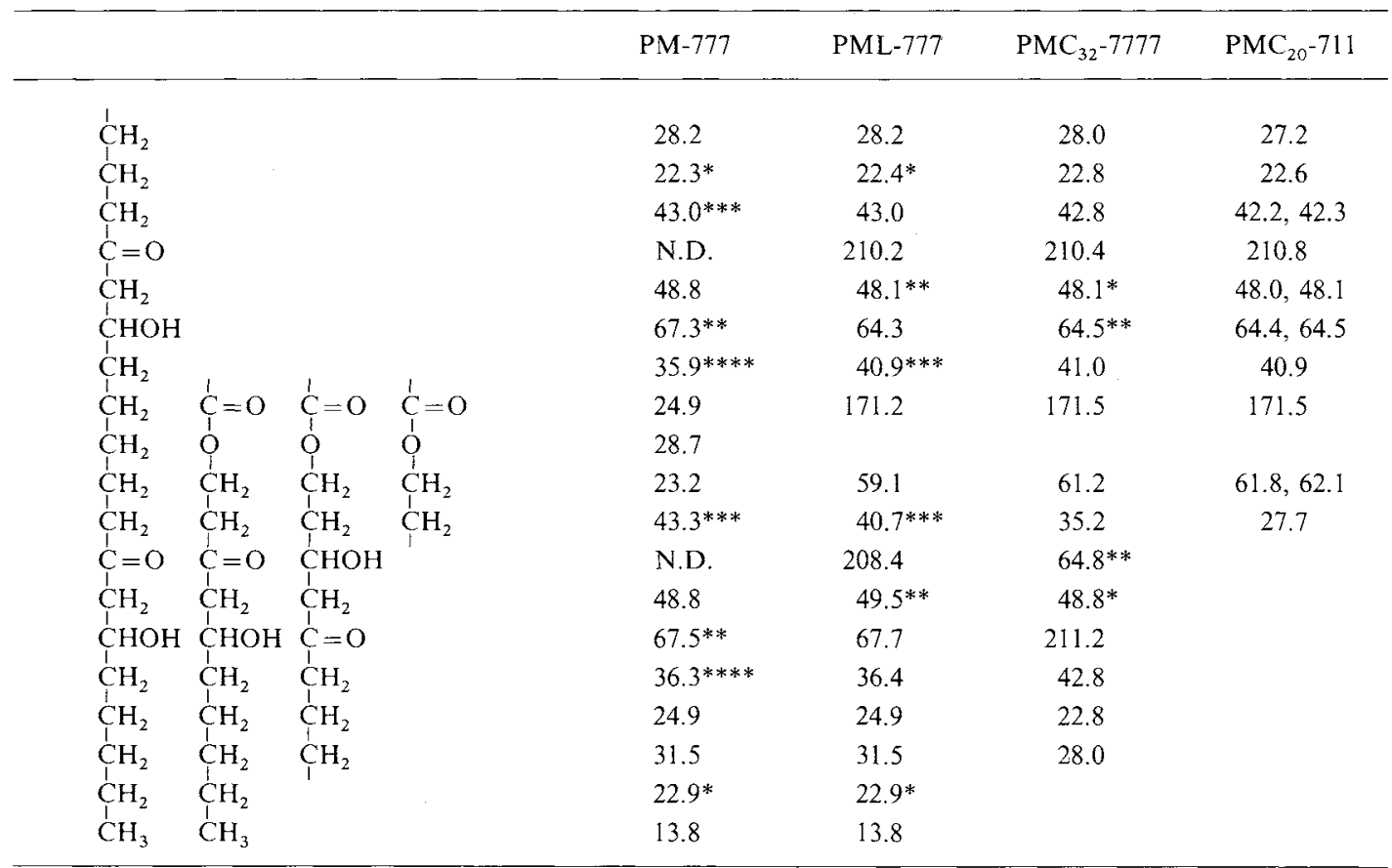

* Assignments are exchangable.

drochloric acid in ethanol to afford the corresponding hydroxyl compound $(\mathbf{1 2}, 14$ and 16). The yields were 43 to $7 \%$, respectively. Reaction of the thioketals (12, 14 and 16) with mercuric chloride in aqueous acetonitrile at room temperature gave the desired PM-toxin analogues (42 to $62 \%$ yields), respectively.

The structures of all the analogues were confirmed by means of their MS data and elemental analyses, ${ }^{13} \mathrm{C}$ - (Table I) and ${ }^{1} \mathrm{H}$ NMR spectra, and IR spectra described in the experimental section.

The relative biological activities of the three newly synthesized analogues (PML-777, $\mathrm{PMC}_{32}-7777$ and $\mathrm{PMC}_{20}-711$ ) and of $\mathrm{PM}-$ 777 were evaluated for their stimulation of NADH oxidation in isolated Tms-corn mitochondria, ${ }^{13)}$ and compared by estimating the concentration required to effect $50 \%$ of each maximum activity $\left(\mathrm{ED}_{50}\right.$, Fig. 5). PM-777 is a synthetic PM-toxin analogue composed of a carbon-chain skeleton and with activities comparable to those of natural PMtoxins.

Although the orientation and spacing of the oxygenic groups of PML-777 were the same as those of PM-777, the analogue PML-777 was, unexpectedly, about 100-times less active than PM-777. This clearly shows that the introduction of an ester linkage into the carbon-chain skeleton of the toxin molecule caused a drastic loss of activity. Therefore, we conclude that the carbon-carbon chain skeleton of the PMtoxin molecule was an important factor for maximum activity. The low activity of PML777 relative to $\mathrm{PM}-777$ cannot be clearly explained at the present stage; however, it is possible that disturbance of the formation of optimal conformations for maximum activity was one of the major factors. When the relative activity between PML-777 and PM-777 was compared in detail, the activity of PML777 at a higher concentation of around $10^{-7} \mathrm{M}$ appeared that of PM-777. Perhaps detoxifi- 


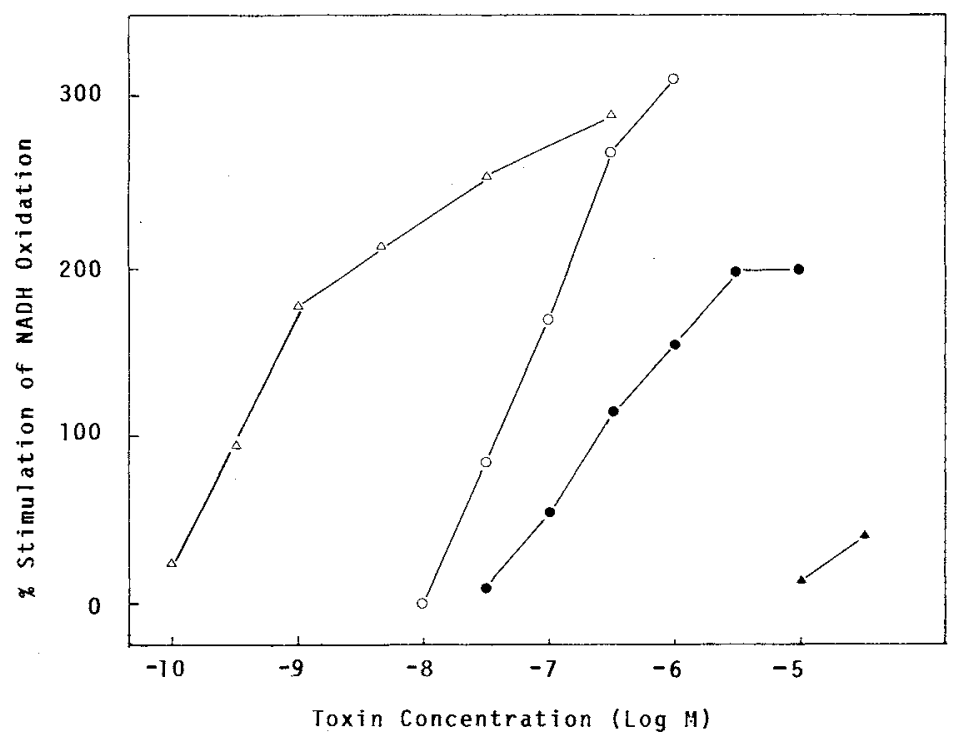

Fig. 5. Comparative Effects of Synthetic PM-Toxin Analogues on the Oxidation of NADH by Mitochondria Isolated from Susceptible W64A-Tms Corn.

$\triangle \mathrm{PM}-777$; O PML-777; $\odot \mathrm{PMC}_{32}-7777 ; \boldsymbol{\Delta} \mathrm{PMC}_{20}-711$.

cation due to immediate hydrolytic-cleavage of the ester linkages in the mitochondria occurred and, therefore, the activity of PML-777 at the lower concentration of around $10^{-8} \mathrm{M}$ was strikingly reduced.

The cyclic analogue $\mathrm{PMC}_{32}-7777$ was 1000 times less active than PM-777, but only about 4- to 10-times less active than the corresponding linear analogue PML-777. Since $\mathrm{PMC}_{32}-$ 7777 can be regarded as one of the possible conformations of the linear PML-777, a small decrease in the activity of $\mathrm{PMC}_{32}-7777$ relative to PML-777 might be primarily due to an increase of molecular rigidity by ring formation. Thus, the biological activity of $\mathrm{PMC}_{32}-7777$ was unexpectedly high. Furthermore, $\mathbf{P M C}_{32}-7777$, which was considered to retain higher molecular rigidity than some less potent linear analogues (e.g., PM373 and -575 and $P M-777 t^{8)}$ ) by having either a shorter or conjugated diene spacer, showed virtually identical activity to the linear analogues (Fig. 1). In fact, another cyclic analogue $\left(\mathrm{PMC}_{20^{-}}-711\right)$ that is smaller than $\mathrm{PMC}_{32}-7777$ showed drastically decreased activity (over 100-times less than $\mathrm{PMC}_{32}$-7777) and was over 10-times less active than the corresponding linear analogue PM-7 (PM-288). ${ }^{7}$ These results suggest that the active conformation of the linear analogue PML-777 may resemble that of the cyclic analogue $\mathrm{PMC}_{32}-7777$, but not $\mathrm{PMC}_{20^{-}}-711$.

These synthetic analogues exhibited specificity because they had no significant effect on an NADH oxidation assay in resistant corn mitochondria with normal cytoplasm even at high concentrations (data not shown).

In summary, we prepared three new PMtoxin analogues containing oxygen atoms in the carbon-chain skeleton and clarified that this skeleton was an important structure for the maximum biological activity of PM-toxins. We also found that even the cyclic analogue $\mathrm{PMC}_{32}-7777$ retained considerable activity. The finding of bioactive PML-777 might be helpful in investigating active conformations of the PM-toxin. When the chiral forms of both PM-777 and PML-777 are synthesized, a comparison of each conformational structure determined by means of an X-ray analysis might reveal the most preferable conformation for maximum biological activity.

A synthesis of both chiral analogues is currently in progress. 


\section{Experimental}

Infrared spectra (IR) were obtained using a Shimadzu IR-435 spectrometer with films on $\mathrm{NaCl}$ plates or with $\mathrm{KBr}$ disks. The NMR data were obtained using JEOL JNM FX-90Q and FX-400 spectrometers. High-resolution mass spectra (HR-MS) and field-desorption mass spectra (FD-MS) were obtained on a Hitachi M-80 spectrometer.

Dimethyl, 3,9-dioxoundacadioate-3,9-di(ethylenedithio)ketal (2). Boron trifluoride etherate $(15 \mathrm{ml})$ was added to a solution of bisoxoester $1^{10)}(42.5 \mathrm{~g}, 156 \mathrm{~mm})$ and $1,2-$ ethanedithiol $(32.4 \mathrm{~g}, 343 \mathrm{~mm})$ in dry dichloromethane $(400 \mathrm{ml})$. After $18 \mathrm{hr}$ of stirring at room temperature, the mixture was washed with water and concentrated to afford a yellow solid. Crystallization from $\mathrm{MeOH}$ gave $50.6 \mathrm{~g}(76 \%)$ of $2, \mathrm{mp} 71.5 \sim 72.0^{\circ} \mathrm{C}$. NMR $\delta_{\mathrm{H}}(90 \mathrm{MHz}$, $\left.\mathrm{CDCl}_{3}\right)$ : c. $1.5(6 \mathrm{H}, \mathrm{m})$, c. $2.1(4 \mathrm{H}, \mathrm{m}), 3.04(4 \mathrm{H}, \mathrm{s}), 3.29$ $(8 \mathrm{H}, \mathrm{s}), 3.70(6 \mathrm{H}, \mathrm{s}) . \mathrm{IR} v_{\max }(\mathrm{KBr}) \mathrm{cm}^{-1}: 1735$. HR-MS $m / z$ Found: $\mathrm{M}^{+}$424.0817. Calcd. for $\mathrm{C}_{17} \mathrm{H}_{28} \mathrm{O}_{4} \mathrm{~S}_{4}$ : 424,0868 .

3,9-Dioxoundacadial-3,9-di(ethylenedithio)ketal (3). Thioketal $2(42.4 \mathrm{~g}, 100 \mathrm{~mm})$ in dry tetrahydrofuran (THF, $100 \mathrm{ml})$ was slowly added to a slurry of $\mathrm{LiAlH}_{4}(8 \mathrm{~g}$, $210 \mathrm{~mm})$ in dry THF $(200 \mathrm{ml})$ at $0^{\circ} \mathrm{C}$. The mixture was stirred at room temperature for one hr and then cooled to $0^{\circ} \mathrm{C}$. Water $(8 \mathrm{ml}), 15 \%$ aqueous $\mathrm{NaOH}$ solution $(8 \mathrm{ml})$, and water $(24 \mathrm{ml})$ were successively added. The cold mixture was filtered, the precipitate was washed with ethyl ether, and the filtrate was concentrated to afford a white solid of the crude diol $(32.8 \mathrm{~g}, 89 \%)$.

Dimethyl sulfoxide $(33.3 \mathrm{ml}, 431 \mathrm{~mm})$ dissolved in dry $\mathrm{CH}_{2} \mathrm{Cl}_{2}(100 \mathrm{ml})$ was added to a solution of oxalyl chloride $(16.7 \mathrm{ml}, 184 \mathrm{~mm})$ in dry $\mathrm{CH}_{2} \mathrm{Cl}_{2}(450 \mathrm{ml})$ at $-50^{\circ}$ to $-60^{\circ} \mathrm{C}$. The mixture was stirred for $2 \mathrm{~min}$, and the diol $(32.7 \mathrm{~g}, 89.0 \mathrm{~mm})$ in dry $\mathrm{CH}_{2} \mathrm{Cl}_{2}(170 \mathrm{ml})$ was added; stirring was continued for an additional $15 \mathrm{~min}$. Triethylamine $(125 \mathrm{mi})$ was next added, and the mixture was stirred for $5 \mathrm{~min}$ before being allowed to warm to room temperature. Water was then added and the aqueous layer was extracted with $\mathrm{CH}_{2} \mathrm{Cl}_{2}$. The combined extracts were washed with saturated $\mathrm{NaCl}$ solution, dried over anhydrous $\mathrm{MgSO}_{4}$, and concentrated. The residue was chromatographed on silica gel with EtOAc--toluene (1:9) to afford an oil of $3(32.2 \mathrm{~g}, 99 \%)$. NMR $\delta_{\mathrm{H}}(90 \mathrm{MHz}$, $\left.\mathrm{CDCl}_{3}\right): c .1 .5(6 \mathrm{H}, \mathrm{m}), 2.0(4 \mathrm{H}, \mathrm{m}), 2.92(4 \mathrm{H}, \mathrm{d}, J=2 \mathrm{~Hz}$, $\mathrm{OH}), 3.34(8 \mathrm{H}, \mathrm{s}), 9.79(2 \mathrm{H}, \mathrm{t}, J=2 \mathrm{~Hz})$. IR $v_{\max }$ (film) $\mathrm{cm}^{-1}: 1735,1715$ (s). HR-MS $m / \mathrm{z}$ Found: $\mathrm{M}^{+}$ 364.0677. Calcd. for $\mathrm{C}_{15} \mathrm{H}_{24} \mathrm{O}_{2} \mathrm{~S}_{4}: 364.0658$.

Aldol condensation of 3 with iso-PrOAc or tert-BuOAc. To a THF $(50 \mathrm{ml})$ solution of lithium disopropylamide prepared from diisopropylamine $(12.14 \mathrm{~g}, 120 \mathrm{~mm})$ and $n$ butyllithium (hexane solution, $62.5 \mathrm{ml}, 100 \mathrm{~mm}$ ) was added dropwise a dry THF $(50 \mathrm{ml})$ solution of iso-PrOAc $(12.3 \mathrm{~g}$, $120 \mathrm{~mm}$ ) at $-78^{\circ} \mathrm{C}$ over $45 \mathrm{~min}$. After stirring for $10 \mathrm{~min}$, a solution of $3(18.2 \mathrm{~g} 50 \mathrm{~mm})$ in dry THF $(40 \mathrm{ml})$ was added dropwise for $15 \mathrm{~min}$. The mixture was stirred for $2 \mathrm{hr}$ at $-78^{\circ} \mathrm{C}$, quenched with EtOH $(20 \mathrm{ml})$, and warmed to ambient temperature. Water was added and the aqueous layer was extracted with diethyl ether. The ether extracts were washed with sat. $\mathrm{NaCl}$ solution and dried over $\mathrm{MgSO}_{4}$. The condensed filtrate was chromatographed on silica gel with EtOAc- $n$-hexane $(3: 7)$ to afford an oil of $4(16.7 \mathrm{~g}, 62 \%)$. The tert-BuOAc-adduct 5 was also obtained quantitatively.

4. $\mathrm{NMR} \delta_{\mathrm{H}}\left(90 \mathrm{MHz}, \mathrm{CDCl}_{3}\right): 1.19(6 \mathrm{H}, \mathrm{t}, J=7 \mathrm{~Hz})$, $2.50(4 \mathrm{H}, \mathrm{d}, J=6 \mathrm{~Hz}), 3.31(8 \mathrm{H}, \mathrm{s}), 3.69(2 \mathrm{H}, \mathrm{d}, J=3 \mathrm{~Hz}$, $\mathrm{OH}), 4.17(4 \mathrm{H}, \mathrm{q}, J=7 \mathrm{~Hz}), 4.40(2 \mathrm{H}, \mathrm{m})$. IR $v_{\max }$ (film) $\mathrm{cm}^{-1}: 3450$, 1725. HR-MS $m / z$ Found: $\mathrm{M}^{+}$ 540.1751. Calcd. for $\mathrm{C}_{23} \mathrm{H}_{40} \mathrm{O}_{6} \mathrm{~S}_{4}: 540.1706$.

5. NMR $\delta_{\mathrm{H}}\left(90 \mathrm{MHz}, \mathrm{CDCl}_{3}\right): 1.46(9 \mathrm{H}, \mathrm{s}), 2.42(4 \mathrm{H}, \mathrm{d}$, $J=7 \mathrm{~Hz}), 3.30(8 \mathrm{H}, \mathrm{s}), 3.70(2 \mathrm{H}, \mathrm{d}, J=3 \mathrm{~Hz}, \mathrm{OH}), 4.36$ $(2 \mathrm{H}, \mathrm{m})$. IR $v_{\max }(\mathrm{film}) \mathrm{cm}^{-1}: 3450,1720$. HR-MS $\mathrm{m} / \mathrm{z}$ Found: $\mathrm{M}^{+}$596.2318. Calcd. for $\mathrm{C}_{27} \mathrm{H}_{48} \mathrm{O}_{6} \mathrm{~S}_{4}$ : 596.2330 .

3, 13-Di(tetrahydropyranyl)oxy-5,11-dioxopentadecadioic acid-5,11-di(ethylenedithio)ketal (8) To a solution of bisethyl ester $4(16.7 \mathrm{~g}, 30.9 \mathrm{~mm})$ and $p$-TsOH $(445 \mathrm{mg})$ in dry dioxane $(125 \mathrm{ml})$ was added dropwise dihydropyran $(17.8 \mathrm{ml})$ with stirring at $10^{\circ} \mathrm{C}$. After $20 \mathrm{~min}$, powdered $\mathrm{NaHCO}_{3}$ (c. $2 \mathrm{~g}$ ) was added, and the filtrate was concentrated to afford a crude oil of 6 . Sodium hydroxide $(12 \mathrm{~g})$ was added to a solution of 6 in $80 \%$ aqueous $\mathrm{MeOH}$ $(200 \mathrm{ml})$ at $0^{\circ} \mathrm{C}$. After $2 \mathrm{hr}$ of stirring at room temperature, the mixture was acidified with dilute $\mathrm{HCl}$ and extracted with EtOAc. The combined extract was washed with water, dried over $\mathrm{MgSO}_{4}$, and concentrated. The residue was chromatographed on silica gel, and elution with EtOAc-toluene $(3: 7)$ gave a slightly yellow powder of $8(15.5 \mathrm{~g}, 77 \%)$. NMR $\delta_{\mathrm{H}}\left(90 \mathrm{MHz}, \mathrm{CDCl}_{3}\right):$ c. 2.7 $(4 \mathrm{H}, \mathrm{m}), 3.27(8 \mathrm{H}, \mathrm{s}), 4.76(2 \mathrm{H}$, br s $)$, c. $8.0(2 \mathrm{H}$, br s, $\mathrm{COOH})$. IR $v_{\max }(\mathrm{film}) \mathrm{cm}^{-1}: 3100,1720(\mathrm{~s}), 1705$. FD-MS $m / z: 652\left(\mathrm{M}^{+}\right)$.

1,15-Dihydroxy-3,13-di(tetrahydropyranyl)oxy-5,11dioxopentadecane-5,11-di(ethylenedithio)ketal (9) A crude oil of 7 was obtained by the same method as that described for 6. Reduction of 7 with $\mathrm{LiAlH}_{4}$ was done by the same method as that described for $\mathbf{3}$, giving an oil of 9 (quantitative yield). NMR $\delta_{\mathrm{H}}\left(90 \mathrm{MHz}, \mathrm{CDCl}_{3}\right): 3.27(8 \mathrm{H}, \mathrm{s}), c$. $4.7(2 \mathrm{H}, \mathrm{m})$. IR $v_{\max }(\mathrm{film}) \mathrm{cm}^{-1}: 3400$. HR-MS $\mathrm{m} / \mathrm{z}$ Found: $\mathrm{M}^{+}$624.2640. Calcd. for $\mathrm{C}_{29} \mathrm{H}_{52} \mathrm{O}_{6} \mathrm{~S}_{4}: 624.2643$.

Esterification of $\mathbf{8}$ with each alcohol $(\mathbf{9}, \mathbf{1 0}$, or 1,3-propanedial) with subsequent removal of the THP ether protecting groups. To a solution of $\mathbf{8}(2.62 \mathrm{~g}, 4.02 \mathrm{~mm}), \mathbf{1 0}(2.79 \mathrm{~g}$, $8.04 \mathrm{~mm}$ ) and 4-DMAP (196 $\mathrm{mg}, 1.6 \mathrm{~mm}$ ) in dry $\mathrm{CH}_{2} \mathrm{Cl}_{2}$ (40 ml) was added $N, N$-dicyclohexylcarbodiimide (DCC, $1.82 \mathrm{~g}, 8.84 \mathrm{~mm}$ ). The mixture was concentrated after $18 \mathrm{hr}$ of stirring at room temperature, and the residue was chromatographed on silica gel with EtOAc- $n$-hexane $(2: 8)$ to afford an oil of $11(2.37 \mathrm{~g}, 45 \%)$. A solution of $\mathbf{1 1}$ 
$(2.18 \mathrm{~g}, 1.66 \mathrm{mM})$ in acetic acid-THF-water $(4: 2: 1,70 \mathrm{ml})$ was stirred at $45^{\circ} \mathrm{C}$ for $6 \mathrm{hr}$ and concentrated. The residue was chromatographed on silica gel, and elution with $\mathrm{MeOH}-\mathrm{CH}_{2} \mathrm{Cl}_{2}(2: 98)$ gave a gum of $12(1.53 \mathrm{~g}, 94 \%)$.

Condensation of $8(5.31 \mathrm{~g}, 8.14 \mathrm{~mm})$ with $9(5.08 \mathrm{~g}$, $8.14 \mathrm{~mm})$, as already described, gave a crude product $\mathbf{1 3}$ $(2.46 \mathrm{~g}, 24 \%)$ after purification by chromatography on silica gel with EtOAc-toluene (2:8). A solution of partially purified $13(2.46 \mathrm{~g}, 1.98 \mathrm{~mm})$ and $0.1 \mathrm{~N} \mathrm{HCl}(0.9 \mathrm{ml})$ in EtOH $(80 \mathrm{ml})$ containing toluene $(10 \mathrm{ml})$ was refluxed for 15 min. Powdered $\mathrm{NaHCO}_{3}$ was added and the filtrate was concentrated. The residue was chromatographed on silica gel, and elution with EtOAc-toluene (2:8) gave a gum of $14(480 \mathrm{mg}, 27 \%)$. Compound $16(450 \mathrm{mg}, 11 \%)$ as an oil was obtained through a similar procedure to that described for 14.

12. $\mathrm{NMR} \delta_{\mathrm{H}}\left(90 \mathrm{MHz}, \mathrm{CDCl}_{3}\right): 0.89(6 \mathrm{H}$, brt $), 2.35$ $(4 \mathrm{H}, \mathrm{t}, J=7 \mathrm{~Hz}), 2.51(4 \mathrm{H}, \mathrm{d}, J=6 \mathrm{~Hz}), 3.31,3.33$ (each $8 \mathrm{H}$, s), 3.16, $3.70($ each $2 \mathrm{H}, \mathrm{d}, J=3 \mathrm{~Hz}, \mathrm{OH}), 3.96(2 \mathrm{H}, \mathrm{m}), c$. $4.4(6 \mathrm{H}, \mathrm{m})$. IR $v_{\max }($ film $) \mathrm{cm}^{-1}: 3450,1725$. FD-MS $m / z$ : $976\left(\mathrm{M}^{+}\right)$.

14. NMR $\delta_{\mathrm{H}}\left(90 \mathrm{MHz}, \mathrm{CDCl}_{3}\right): 2.53(4 \mathrm{H}, \mathrm{d}, J=6 \mathrm{~Hz})$, 3.32 ( $16 \mathrm{H}, \mathrm{s}), 3.60,3.70$ (each $2 \mathrm{H}$, br. s, OH), $4.29(4 \mathrm{H}$, t. like), c. $4.1,4.4($ each $2 \mathrm{H}, \mathrm{m})$. IR $v_{\max }\left(\right.$ film) $\mathrm{cm}^{-1}: 3450$, 1725. FD-MS $m / z$ : $905\left(\mathrm{M}^{+}+\mathrm{H}\right)$.

16. $\mathrm{NMR} \delta_{\mathrm{H}}\left(90 \mathrm{MHz}, \mathrm{CDCl}_{3}\right):$ c. $2.1(8 \mathrm{H}, \mathrm{m}), 2.52$, 2.54 (each $2 \mathrm{H}, \mathrm{d}, J=7 \mathrm{~Hz}), 3.31(8 \mathrm{H}, \mathrm{s}), 3.70(2 \mathrm{H}, \mathrm{d}$, $J=3 \mathrm{~Hz}, \mathrm{OH}), 4.28(4 \mathrm{H}, \mathrm{t}, J=6 \mathrm{~Hz}), 4.38(2 \mathrm{H}, \mathrm{m})$. IR $v_{\max }$ (film) $\mathrm{cm}^{-1}: 3450$, 1730. HR-MS $m / z$ Found: $\mathrm{M}^{+}$ 524.1411. Calcd for $\mathrm{C}_{22} \mathrm{H}_{36} \mathrm{O}_{6} \mathrm{~S}_{4}$ : 524.1393 .

PML-777 and cyclic analogues. A suspension of $\mathbf{1 2}$ $(1.53 \mathrm{~g}, 1.57 \mathrm{~mm})$, mercuric chloride $(3.65 \mathrm{~g})$ and mercuric oxide $(1.13 \mathrm{~g})$ in water $(4.8 \mathrm{ml})$ and acetonitrile $(80 \mathrm{ml})$ was stirred for $4 \mathrm{hr}$ at $20^{\circ} \mathrm{C}$. The cooled mixture was filtered and the precipitate was washed with chloroform. The filtrate was washed with water, saturated ammonium chloride solution and again with water. Evaporation of the solvent and subsequent precipitation from acetone in $n$ hexane gave a colorless powder of PML-777 (690 $\mathrm{mg}, 60 \%)$.

Two cyclic analogues were also similarly obtained.

$P M L$-777. NMR $\delta_{\mathrm{H}}\left(400 \mathrm{MHz}, \mathrm{CDCl}_{3}\right): 0.89(6 \mathrm{H}, \mathrm{t}$, $J=7 \mathrm{~Hz}), c .1 .38 \sim 1.53(4 \mathrm{H}, \mathrm{m}), 1.57(4 \mathrm{H}$, quint, $J=7 \mathrm{~Hz})$, $2.48(2 \mathrm{H}$, d. like, $J=7 \mathrm{~Hz}), 2.48(2 \mathrm{H}$, d. like, $J=6 \mathrm{~Hz}), 2.55$ $(2 \mathrm{H}, \mathrm{dd}, J=17,8 \mathrm{~Hz})$, c. $2.59(2 \mathrm{H}, \mathrm{dd}, J=17,4 \mathrm{~Hz})$, c. 2.60 $(2 \mathrm{H}, \mathrm{dd}, J=17,3 \mathrm{~Hz}), 2.65(2 \mathrm{H}, \mathrm{dd}, J=17,8 \mathrm{~Hz}), 2.79$ $(4 \mathrm{H}, \mathrm{t}, J=6 \mathrm{~Hz}), 2.86,2.88($ each $1 \mathrm{H}$, br. d, OH), 3.45, 3.49 (each $\mathrm{IH}, \mathrm{d}, J=2 \mathrm{~Hz}, \mathrm{OH}), 4.07(2 \mathrm{H}$, br. s), $4.38(4 \mathrm{H}, \mathrm{m})$, $4.44(2 \mathrm{H}, \mathrm{m})$. IR $v_{\max }(\mathrm{KBr}) \mathrm{cm}^{-1}: 3400,1720(\mathrm{~s}), 1715$. FD-MS $m / z: 695\left(\mathrm{M}^{+}+\mathrm{Na}\right)$. Anal. Found: C, 61.97; $\mathrm{H}$, 8.95. Calcd. for $\mathrm{C}_{35} \mathrm{H}_{60} \mathrm{O}_{12} \cdot 1 / 2 \mathrm{H}_{2} \mathrm{O}: \mathrm{C}, 61.67 ; \mathrm{H}, 8.96 \%$.

$P_{32}$-7777. A colorless powder $(135 \mathrm{mg}, 42 \%)$ from acetone in $n$-hexane. NMR $\delta_{\mathrm{H}}\left(400 \mathrm{MHz}, \mathrm{CDCl}_{3}\right): 1.28$ $(8 \mathrm{H}, \mathrm{m}), 1.60(8 \mathrm{H}, \mathrm{m}), 1.77(4 \mathrm{H}, \mathrm{m}), 2.46,2.47$ (each $4 \mathrm{H}, \mathrm{t}$, $J=7 \mathrm{~Hz}), 2.53,2.59($ each $4 \mathrm{H}$, d. like, $J=7 \mathrm{~Hz}), 2.63(2 \mathrm{H}$, dd, $J=17,5 \mathrm{~Hz}), 2.68(2 \mathrm{H}, \mathrm{dd}, J=17,7 \mathrm{~Hz}), 3.403 .66$ (each $2 \mathrm{H}, \mathrm{m}, \mathrm{OH}), 4.18,4.47$ (each $2 \mathrm{H}, \mathrm{m})$. IR $v_{\max }$
$(\mathrm{KBr}) \mathrm{cm}^{-1}: 3400,1720(\mathrm{~s}), 1715$ (s), 1700. FD-MS $m / z$ : $623\left(\mathrm{M}^{+}+\mathrm{Na}\right), 601\left(\mathrm{M}^{+}+\mathrm{H}\right)$. Anal. Found: $\mathrm{C}, 58.77 ; \mathrm{H}$, 7.88. Calcd. for $\mathrm{C}_{30} \mathrm{H}_{48} \mathrm{O}_{12} .1 / 2 \mathrm{H}_{2} \mathrm{O}: \mathrm{C}, 59.11 ; \mathrm{H}, 8.05 \%$.

$P M C_{20}-711$. A slightly yellowish solid $(167 \mathrm{mg}, 52 \%)$ after purification by chromatography on silica gel with EtOAc-toluene $(3: 7)$. NMR $\delta_{\mathrm{H}}\left(400 \mathrm{MHz}, \mathrm{CDCl}_{3}\right): 1.25$ $(2 \mathrm{H}, \mathrm{m}), 1.62(4 \mathrm{H}, \mathrm{m}), 2.00(2 \mathrm{H}$, quint, $J=5 \mathrm{~Hz}), 2.45(4 \mathrm{H}$, $\mathrm{t}, J=7 \mathrm{~Hz}), 2.54(2 \mathrm{H}, \mathrm{dd}, J=16,6 \mathrm{~Hz}), 2.58(2 \mathrm{H}, \mathrm{dd}$, $J=16,5 \mathrm{~Hz}), 2.65(2 \mathrm{H}, \mathrm{dd}, J=17,5 \mathrm{~Hz}), 2.73(2 \mathrm{H}, \mathrm{dd}$, $J=17,7 \mathrm{~Hz}), 3.49(1 \mathrm{H}, \mathrm{d}, J=2 \mathrm{~Hz}, \mathrm{OH}), 3.50(1 \mathrm{H}, \mathrm{d}$, $J=3 \mathrm{~Hz}, \mathrm{OH}), 4.25(4 \mathrm{H}, \mathrm{m}), 4.46(2 \mathrm{H}, \mathrm{m})$. IR $v_{\max }$ $(\mathrm{KBr}) \mathrm{cm}^{-1}: 3500,3400,1720,1705$. HR-MS $m / z$ Found: $\mathrm{M}^{+}-\mathrm{H}_{2} \mathrm{O}, 354.1626$. Calcd. for $\mathrm{C}_{18} \mathrm{H}_{26} \mathrm{O}_{7}: 354.1676$.

Isolation of mitochondria and bioassays. The methods for the isolation of mitochondria and NADH oxidation assays have been reported previously. ${ }^{13)}$

Acknowledgments. The authors thank Dr. J. Uzawa, Mrs. T. Chijimatsu and Mr. Y. Esumi of the Institute of Physical and Chemical Research for NMR and mass spectra. This work was supported in part by a Grant-inAid for Scientific Research from the Ministry of Education, Science and Culture of Japan.

\section{References}

1) Y. Kono, S. J. Danko, Y. Suzuki, S. Takeuchi and J. M. Daly, Tetrahedron Lett., 1983, 3803.

2) S. J. Danko, Y. Kono, J. M. Daly, Y. Suzuki, S. Takeuchi and D. A. McCrely, Biochemistry, 23, 759 (1984).

3) Y. Kono, Y. Suzuki, S. Takeuchi, H. W. Knoche and J. M. Daly, Agric. Biol. Chem., 49, 559 (1984).

4) Y. Kono and J. M. Daly, Bioorg. Chem., 8, 391 (1979).

5) Y. Kono, S. Takeuchi, A. Kawarada, J. M. Daly and H. W. Knoche, Tetrahedron Lett., 1980, 1537.

6) Y. Kono, S. Takeuchi, A. Kawarada, J. M. Daly and H. W. Knoche, Bioorg. Chem., 10, 206 (1981).

7) Y. Suzuki, S. J. Danko, Y. Kono, J. M. Daly and S. Takeuchi, Agric. Biol. Chem., 49, 149 (1985).

8) Y. Suzuki, L. W. Coleman, J. M. Daly, Y. Kono, H. W. Knoche and S. Takeuchi, Phytochemistry, 26,687 (1987).

9) Y. Suzuki, S. J. Danko, Y. Kono, J. M. Daly, H. W. Knoche and S. Takeuchi, Agric. Biol. Chem., 52, 15 (1988).

10) S. N. Huckin and L. Weiler, J. Am. Chem. Soc., 96, 1082 (1974).

11) A. J. Mancuso, Shui-Lung Huang and D. Swern, $J$. Org. Chem., 43, 2480 (1978).

12) A. Hassner and V. Alexanian, Tetrahedron Lett., 1978, 4475.

13) Y. Suzuki, S. J. Danko, J. M. Daly, Y. Kono, H. W. Knoche and S. Takeuchi, Plant Physiol., 73, 440 (1983). 